\title{
Interaction of Warfarin with Herbs Based on Pharmacokinetic and Pharmacodynamic Parameters
}

\author{
Amelia Soyata ${ }^{1}$, Aliya Nur Hasanah ${ }^{2}$, Taofik Rusdiana ${ }^{1, *}$ \\ ${ }^{1}$ Department of Pharmaceutics and Pharmaceutical Technology, Faculty of Pharmacy, Universitas \\ Padjadjaran, Sumedang, Indonesia \\ ${ }^{2}$ Department of Analysis of Pharmaceutical and Medical Chemistry, Faculty of Pharmacy, Universitas \\ Padjadjaran, Sumedang, Indonesia
}

Received : 15 May 2020/Revised : 17 May 2020/Accepted : 5 Jun 2020/ Published:23 Jun 2020

\begin{abstract}
Warfarin is an oral anticoagulant that has been widely used and has strong efficacy, but the use of warfarin is still a concern because of its narrow therapeutic index which cause interactions when co-administration with drugs, herbs or food. This interaction can affect the pharmacokinetics and pharmacodynamics of warfarin and the most fatal effect from warfarin interactions is bleeding. In this review article data on warfarin-herbs interactions were collected based on pharmacokinetic parameters $\left(\mathrm{AUC}_{0-\infty}, \mathrm{C}_{\max }, \mathrm{T}_{1 / 2}, \mathrm{Cl} / \mathrm{F}\right.$, and $\left.\mathrm{V} / \mathrm{F}\right)$, while pharmacodynamic parameters (International normalized ratio (INR), platelet aggregation, AUC INR and Protombine Time). As a result some herbs had significant interactions with warfarin. Herbs that affect warfarin pharmacokinetic were Danshen gegen, echinacea, St. John's wort and caffeine and herbs that affect pharmacodynamic were policosanol, Ginkgo biloba, cranberry, St. John's wort, ginseng, pomegranate, Psidium guajava and curcumin, so co-administration warfarin with herbs need to be considered.
\end{abstract}

\section{Keywords: Warfarin, Interactions, Herbs, Pharmacokinetics, Pharmacodynamics}

\section{Introduction}

Warfarin is an oral anticoagulant that had been widely used since 1954 and prescribed for decades (1). Warfarin is used to prevent thromboembolic complications in a patient with various cardiovascular diseases including atrial fibrillation and thrombosis (2). The anticoagulation effect of warfarin is achieved by inhibit the formation cycle of vitamin $\mathrm{K}$ in the liver. It inhibits vitamin $\mathrm{K}$ epoxide reductase (VKOR) that very important in the formation of factors VII and IX in blood clotting (3). Although warfarin has strong efficacy, the use of warfarin is still a concern because of its narrow therapeutic window, it cause an interaction when co-administration with drugs, herbs, or foods.

Drug-drug interaction occurs every time the effects of the drug are modified by the presence of other drugs which causes therapeutic failure, toxicity, or serious complication (4). Warfarin is included in the top ten of drugs with severe side effects in 2019 (5). Based on a report in the United States, about $58 \%$ patients who take warfarin, they also take herbal medicines to improve their health condition (6,7). While there is 34 warfarin interaction from 133 cases of herb-drug interaction (8), because of that warfarin is one of the most frequently studied drug-related to its interactions. This interaction can affect the pharmacokinetic and pharmacodynamic of warfarin, and the most fatal effect by warfarin interaction is bleeding (9).

Warfarin is metabolized by CYP450 in the liver. Warfarin has $\mathrm{R}$ and $\mathrm{S}$ enantiomer. R-warfarin is metabolized by CYP3A4, CYP1A2, and 
CYP2C19, while S-warfarin mainly metabolized by CYP2C9 $(10,11)$. Many studies have shown that warfarin interactions are mediated by CYP enzymes and protein plasma binding (12). The herbs can influence the enzymes and affect pharmacokinetic and pharmacodynamic of warfarin.

The herbs influence the metabolism enzyme of warfarin by inhibition or induction. A few herbs have been reported inhibit CYP2C9 enzyme including Harpagophytum procumbens, Trifolium pratense (13), Citrus paradise (14), Serenoa repens (15), Glycine max (16), Angelica sinensis (17) while Allium sativum (18), Cannabis sativa (19) are reported induction CYP2C9.

Therefore it is necessary to gather information related to the interaction of warfarin with herbs based on pharmacokinetic and pharmacodynamics parameters, so the administration of warfarin therapy to patients who take certain herbal medicines can be more controlled, and reduce the side effects. This article will gather the information related to the interaction of warfarin with herbs based on its pharmacokinetic and pharmacodynamics parameters.

\section{Methodology}

In this review article, literature was collected from the internet through google scholar, Elsevier, Pubmed, using the keywords "warfarin", "herbdrug interaction", "interaction of warfarin", "the pharmacokinetics of warfarin", "pharmacokinetic drug interaction", "pharmacodynamics interaction", "pharmacodynamics of warfarin". The data of warfarin interaction with some herbs were obtained based on the result of previous studies and we do further searches from the relevant references. Inclusion criteria are articles which have pharmacokinetic parameters, pharmacodynamic parameters, publication year > 2000, and articles that have references on warfarin, herbs, and drug interactions. The number of literature that has been collected was 145 articles, but only 65 articles included based on the inclusion criteria. It is illustrated by Figure 1.

80 articles exluded, that is :

- Articles not in English $(n=4)$

- Case Report $(n=3)$

- Articles< $2000(\mathrm{n}=12)$

- Unrelated articles $(n=61)$

Initial selected Article

$(\mathrm{n}=145)$

65 articles selected after initial screening

Figure 1. Flow Chart Of the Literature Review 


\section{Discussion}

There are two classifications of drug interactions: pharmacokinetic interactions and pharmacodynamic interactions. Pharmacokinetic interaction is associated with absorption, distribution, metabolism, and excretion. It can change drug concentration in blood. Pharmacodynamic interaction is related to drug effects, it is classified into three groups such as direct effect at receptor function, interference with a biological or physiological control process and additive/opposed pharmacological effect (20). Pharmacokinetic and pharmacodynamic interactions occur due to the presence of other substances that affect the drug, for example when using herbs simultaneously, the active ingredients of these herbs cause the interactions. This interaction can be seen from changes in pharmacokinetic parameters and pharmacodynamic parameters.

The pharmacokinetic parameters are area under curve $0^{-\infty}\left(\mathrm{AUC}_{\left.0^{-} \infty\right)}\right.$ is area under the plasma concentration time in zero to infinity. $C_{\max }$ is the maximum concentration of drug in plasma. $\mathrm{T}_{\max }$ is the maximum time to reach maximum plasma concentration. $\mathrm{T}_{1 / 2}$ is time required for drug to decline by half. Clearance $(\mathrm{Cl} / \mathrm{F})$ is the total clearance of drug after oral administration. Volume distribution $(\mathrm{V} / \mathrm{F})$ is the volume of distribution of drug after non-intravenous administration. Mean residence time (MRT). Fu is fraction of unbound drug in plasma (21). The parmacodynamic parameters for warfarin are international normalized ratio (INR), AUC of INR, platelet aggregation, and protombine time (PT). PT is the time for blood to clot (22). This article has summarized the pharmacokinetic interaction of warfarin with herbs based on pharmacokinetic parameters in Table 1 and pharmacodynamic parameters in Table 2.

\subsection{Danshen gegen}

Based on of Zhou et al (23) extract of Danshen gegen (DG) was given to rats after warfarin administration for 5 days show influence on the pharmacokinetic parameters, such as $\mathrm{C}_{\max }, \mathrm{AUC}_{0-\infty}$ and $\mathrm{T}_{\max }$. For $\mathrm{R}$-warfarin, there was a decrease in the $\mathrm{C}_{\max }$ from $1.03 \mathrm{mg} / \mathrm{ml}$ to $0.52 \mathrm{mg} / \mathrm{ml}$, a decrease in the AUC from $13.09 \mathrm{mg} / \mathrm{ml}$ to 6.56 $\mathrm{mg} / \mathrm{ml}$, also decrease in $\mathrm{T}_{1 / 2}$ from 19.74 minutes to 10.98 minutes. For $\mathrm{S}$-warfarin, there was a decrease in $\mathrm{C}_{\max }$ from $1.44 \mathrm{mg} / \mathrm{ml}$ to $0.93 \mathrm{mg} / \mathrm{ml}$, whereas for $\mathrm{AUC}_{0-\infty}$ and $\mathrm{T}_{1 / 2}$ was not significantly different (Table 1).

In conclusion based on Table 1 (23) coadministration of DG extract with warfarin influence the pharmacokinetic parameters of warfarin in rats. It is caused by DG extract's active substances, such as puerarin (1986.0mg/100mg), salvianolic acid B $(2048.3 \mathrm{mg} / 100 \mathrm{mg})$, daidzein (122.5 mg/100 mg), daidzin (190.9 mg /100 mg), protocatechuic aldehyde $(117.3 \mathrm{mg} / 100 \mathrm{mg})$, and the hydrophobic components such as tanshinones (31).

The interaction between DG extract and warfarin is caused by the interaction of DG extract's active substance with cytochrome P450 (CYP450) (32). Tanshinones inhibit CYP3A4 (33). The results of studies on rats, Danshen gegen extract induces CYP1A2 activity around 60\% (34), while on the other side according to Lin (34) tanshinone II A inhibits CYP1A2 (35). Component of Danshen gegen has been analyzed by clinical studies, a sequential studies on this enzyme show that CYP3A and CYP1A1 are inducted by Danshen gegen (8). These findings indicate that there are potential interactions for drugs that are substrates for CYP3A4 or CYP1A2 when given together with Danshen gegen. As we know that the main metabolism of warfarin occurs in the liver by CYP2C9, CYP1A2, and CYP3A4, so the use of warfarin and Danshen gegen simultaneously needs to be reconsidered.

\subsection{Policosanol and Echinacea}

Echinacea is one of the herbal medicines that used as immunostimulants from Echinacea purpurea and Echinacea angustifolia (36). Policosanol is a complex mixture of alcohol obtained by extracting the Saccharum officinarum (37). Policosanol has been reported to reduce cholesterol levels (38), and can be used in patients with cardiovascular disease who receive warfarin therapy.

Administration of $25 \mathrm{mg}$ warfarin to healthy volunteers simultaneously with echinacea (a mixture of $600 \mathrm{mg}$ Echinacea angustifolia and 675 $\mathrm{mg}$ of Echinacea purpurea which is standardized with $5.75 \mathrm{mg}$ alkamide per tablet), and policosanol 
Table 1. Pharmacokinetic Interaction of Warfarin with Herbs

\begin{tabular}{|c|c|c|c|c|c|c|c|c|c|c|c|}
\hline \multirow[t]{2}{*}{ No } & \multirow[t]{2}{*}{ Herb } & \multirow[t]{2}{*}{ Phase } & \multicolumn{8}{|c|}{ Pharmacokinetic Parameters } & \multirow[t]{2}{*}{ Ref } \\
\hline & & & $\begin{array}{l}\mathrm{AUC}_{0^{-} \infty} \\
(\mu \mathrm{g} \mathrm{mL} / \mathrm{h})\end{array}$ & $\begin{array}{c}\mathrm{Cmax} \\
(\mu \mathrm{g} / \mathrm{mL})\end{array}$ & $\begin{array}{c}\text { Tmax } \\
\text { (h) }\end{array}$ & $\begin{array}{l}\mathrm{T}_{1 / 2} \\
(\mathrm{~h})\end{array}$ & $\begin{array}{c}\mathrm{Cl} / \mathrm{F} \\
(\mathrm{mL} / \mathrm{h})\end{array}$ & $\begin{array}{c}\mathrm{V} / \mathrm{F} \\
(\mathrm{L} / \mathrm{kg})\end{array}$ & $\begin{array}{l}\text { MRT } \\
\text { (h) }\end{array}$ & $\mathrm{Fu}$ & \\
\hline \multirow[t]{4}{*}{1} & Danshen & R-warfarin & 13.09 & 1.03 & 2.92 & 19.74 & & & & & \multirow[t]{4}{*}{ (23) } \\
\hline & gegen & R-warfarin + S.miltiorrhiza & 6.56 & 0.52 & 1.71 & 10.98 & & & & & \\
\hline & (Silvia & S-warfarin & 13.09 & 1.03 & 2.92 & 19.74 & & & & & \\
\hline & Miltiorrhiza) & S-warfarin + S.miltiorrhiza & 19.90 & 0.93 & 1.96 & 25.18 & & & & & \\
\hline \multirow[t]{6}{*}{2} & Policosanol & S-warfarin & 53.9 & 1.3 & 1.7 & 38.6 & 267.3 & 0.21 & & 0.01 & \multirow{6}{*}{ (24) } \\
\hline & & S-warfarin + Policosanol & 51.9 & 1.3 & 1.2 & 38.6 & 278 & 0.23 & & 0.01 & \\
\hline & \multirow[t]{4}{*}{ Echinacea } & S-warfarin + Echinacea & 49 & 1.3 & 1.9 & 36.5 & 289.7 & 0.23 & & 0.01 & \\
\hline & & R-warfarin & 79.4 & 1.3 & 2 & 50.6 & 178.3 & 0.19 & & 0.01 & \\
\hline & & R-warfarin +Policosanol & 77.8 & 1.4 & 1.2 & 38.6 & 278 & 0.20 & & 0.01 & \\
\hline & & R-warfarin + Echinacea & 49 & 1.2 & 2 & 49.2 & 186.4 & 0.20 & & 0.01 & \\
\hline \multirow[t]{6}{*}{3} & \multirow{6}{*}{$\begin{array}{l}\text { Ginkgo } \\
\text { and } \\
\text { Ginger }\end{array}$} & $S$-warfarin & 68 & 1.7 & 2.1 & 35.8 & 189 & \multirow{6}{*}{$\begin{array}{l}0.12 \\
0.12 \\
0.12 \\
0.12 \\
0.11 \\
0.11\end{array}$} & & 0.48 & \multirow[t]{6}{*}{$(25)$} \\
\hline & & S-warfarin + Ginkgo & 65.8 & 1.8 & 1.4 & 35.1 & 200 & & & 0.47 & \\
\hline & & S-warfarin + Ginger & 66 & 1.7 & 1.6 & 35.7 & 201 & & & 0.48 & \\
\hline & & R-warfarin & 104 & 1.7 & 2.1 & 50.3 & 127 & & & 1.8 & \\
\hline & & R-warfarin + Ginkgo & 102.2 & 1.8 & 1.6 & 48.6 & 126 & & & 1.7 & \\
\hline & & R-warfarin + Ginger & 102.6 & 1.7 & 1.6 & 47.7 & 131 & & & 1.8 & \\
\hline \multirow[t]{4}{*}{4} & \multirow[t]{4}{*}{ Cranberry } & R-warfarin & 108.7 & 1.8 & 1.4 & 55.6 & 123 & & & 0.01 & \multirow[t]{4}{*}{$(26)$} \\
\hline & & R-warfarin + Cranberry & 105.8 & 1.7 & 1.9 & 47.7 & 124 & & & 0.01 & \\
\hline & & S-warfarin & 60.3 & 1.8 & 1.4 & 38.6 & 213 & & & 0.006 & \\
\hline & & S-warfarin + Cranberry & 63 & 1.7 & 1.9 & 34.9 & 204 & & & 0.005 & \\
\hline \multirow[t]{6}{*}{5} & \multirow[t]{2}{*}{ St John's wort } & S-warfarin & 65.4 & 1.89 & 1.29 & 31.7 & 198 & \multirow{6}{*}{$\begin{array}{l}0.12 \\
0.10 \\
0.13 \\
0.10 \\
0.13 \\
0.10\end{array}$} & & 0.34 & \multirow[t]{6}{*}{$(27)$} \\
\hline & & R-warfarin & 120.9 & 1.92 & 1.34 & 51.7 & 110 & & & 0.48 & \\
\hline & And & S-warfarin + St John's wort & 47.7 & 1.82 & 1.26 & 25.1 & 270 & & & 0.36 & \\
\hline & \multirow[t]{3}{*}{ Ginseng } & R-warfarin + St John's wort & 91.1 & 1.84 & 1.34 & 40.3 & 142 & & & 0.47 & \\
\hline & & S-warfarin + Ginseng & 57.8 & 1.93 & 1.30 & 29.2 & 220 & & & 0.39 & \\
\hline & & R-warfarin + Ginseng & 108.1 & 1.89 & 1.30 & 47.9 & 119 & & & 0.46 & \\
\hline \multirow[t]{5}{*}{6} & \multirow{5}{*}{$\begin{array}{c}\text { Pomegranate } \\
\text { Peel } \\
\text { and } \\
\text { Guava } \\
\text { Leaves }\end{array}$} & Warfarin & 106.61 & 3.67 & 6 & 17 & 1.45 & & 25 & & $(28)$ \\
\hline & & Warfarin + Pomegranate & 99.45 & 4.22 & 3 & 21 & 1.54 & & 25 & & \\
\hline & & Warfarin + Elegic Acid & 131.66 & 4.98 & 3 & 16 & 1.17 & & 23 & & \\
\hline & & Warfarin + Guava Leaves & 252.56 & 6.97 & 11 & 17 & 0.61 & & 30 & & \\
\hline & & Warfarin + Quercetin & 115.90 & 5.43 & 5 & 18 & 1.14 & & 22 & & \\
\hline 7 & Curcumin & Warfarin & 16.68 & 1.14 & 3.17 & 19.47 & & & & & (29) \\
\hline & & $\begin{array}{c}\text { Warfarin + Curcumin } 25 \\
\mathrm{mg} / \mathrm{kg}\end{array}$ & 21.93 & 1.49 & 1.33 & 13.28 & & & & & \\
\hline & & $\begin{array}{c}\text { Warfarin }+ \text { Curcumin } 50 \\
\mathrm{mg} / \mathrm{kg}\end{array}$ & 16.34 & 1.15 & 1.67 & 19.29 & & & & & \\
\hline & & $\begin{array}{c}\text { Warfarin }+ \text { Curcumin } 100 \\
\mathrm{mg} / \mathrm{kg}\end{array}$ & 26.64 & 1.71 & 2.67 & 17.39 & & & & & \\
\hline 8 & Caffeine & Warfarin & 109.3 & 1.9 & 8.1 & 34 & & 0.2 & & & $(30)$ \\
\hline & & Warfarin + Caffeine & 147.2 & 1.9 & 7.6 & 49,1 & & 0.2 & & & \\
\hline
\end{tabular}


Table 2. Pharmacodynamics Interaction of Warfarin with Herbs

\begin{tabular}{|c|c|c|c|c|c|c|c|}
\hline No & Herb & Phase & $\begin{array}{c}\text { INR } \\
\text { Value }\end{array}$ & $\begin{array}{c}\text { Platelet } \\
\text { Aggregation }\end{array}$ & $\begin{array}{l}\text { AUC of } \\
\text { INR }\end{array}$ & PT (s) & References \\
\hline \multirow[t]{3}{*}{1} & Policosanol & Warfarin & 1.7 & & 52.7 & & \multirow{3}{*}{ (24) } \\
\hline & and Echinacea & Warfarin + Policosanol & 1.9 & & 55.2 & & \\
\hline & & Warfarin + Echinacea & 1.8 & & 55.2 & & \\
\hline \multirow[t]{3}{*}{2} & Ginkgo & Warfarin & 1.12 & 7.5 & 124 & & \multirow[t]{3}{*}{ (25) } \\
\hline & Ginger & Warfarin + Ginkgo & 1.14 & 8.4 & 121 & & \\
\hline & & Warfarin + Ginger & 1.12 & 8.1 & 125 & & \\
\hline \multirow[t]{2}{*}{3} & Cranberry & Warfarin & 1.2 & & 96 & & \multirow[t]{2}{*}{ (26) } \\
\hline & & Warfarin + Cranberry & 1.2 & & 119.2 & & \\
\hline \multirow[t]{3}{*}{4} & St John's wort & Warfarin & 1.14 & 7.7 & 111 & & \multirow[t]{3}{*}{ (27) } \\
\hline & and Ginseng & Warfarin + St John's wort & 1.12 & 7.5 & 88.3 & & \\
\hline & & Warfarin + Ginseng & 1.13 & 7.1 & 111.1 & & \\
\hline \multirow[t]{6}{*}{5} & Pomegranate & Warfarin & 19 & & & 191 & \multirow[t]{6}{*}{ (28) } \\
\hline & Peel and Guava & Warfarin + Pomegranate & 42 & & & 360 & \\
\hline & Leaves Extract & Peel & & & & & \\
\hline & & Warfarin + Elegic Acid & 51 & & & 414 & \\
\hline & & Warfarin + Guava Leaves & 52 & & & 425 & \\
\hline & & Warfarin + Quercetin & 55 & & & 448 & \\
\hline
\end{tabular}

tablet $10 \mathrm{mg} 2$ times a day for 2 weeks show that policosanol and echinacea did not provide a echinacea increase the total clearance of S-warfarin but has no effect on R-warfarin. Administration of policosanol has no significant effect on the pharmacokinetic and pharmacodynamic parameters of warfarin (Table 1) (24).

Echinacea tablets contain more than $1 \%$ phenolic compound (caftaric acid, chlorogenic acid, echinacoside, and chichoric acid) as well as alkamides (2-ena and 2.4 dienes) (39). In Abdul study (24) tablets were used with the same content as the formulation in the study of Gorski et al (39). There was no effect of policosanol in pharmacokinetic of warfarin (39), so it could be linked to the cause of the absence of pharmacokinetic changes. Policosanol has been reported reduce blood cholesterol levels at a dose of $20 \mathrm{mg}$ per day (40), but the results of Abdul (24) did not show any significant changes in platelet aggregation after being given policosanol $20 \mathrm{mg}$ for 2 weeks (24). Other study reported no blood clotting factors after 8 weeks of treatment with policosanol $10 \mathrm{mg}$ per day in cholesterolemia patients (41). Also, there is no significant relationship between the CYP2C9 or VKORC1 gene $(40,41)$. The relatively small number of samples can influence the interpretation of the results. Although the results of Abdul et al (24) show that the use of warfarin together with significant interaction, the use of this substance needs to be maintained continuously.

\subsection{Ginkgo and Ginger}

Jiang et al (25) show there was no significant changes on pharmacokinetic and pharmacodynamics parameters of S-warfarin and $\mathrm{R}$-warfarin in healthy volunteers (Table 1 and Table 2). It similar with Kumar (43) on administration of ginkgo with warfarin from international normalized ratio (INR) in patients consuming $100 \mathrm{mg}$ of ginkgo extract daily for 4 weeks, it showed that ginkgo did not affect the warfarin (44).

Table 1 showed the level of urine excretion was not change after administration of ginkgo and ginger which means that these two herbs did not affect CYP2C9 activity. When $60 \mathrm{mg}$ of ginkgo extract was given 4 times daily for 28 days to healthy volunteers, there was no activity in CYP3A4, CYP1A2, CYP2E1, or CYP2D6. Although there are no interactions, the content of ginkgo has been reported to inhibit and induce cytochrome $\mathrm{P} 450(43,44)$. In vitro studies the use of different doses of ginkgo, for example, Egb 761 extract contain less than $5 \mathrm{ppm}$ ginkgolide acid affect the activity of CYP (47). 
Ginkgolides from ginkgo can inhibit platelet activating factor (48). However, there is also evidence that ginkgo did not affect adenosine diphosphate or platelet aggregation (49). Ginkgo also did not provide platelet or coagulation activity at doses of 120, 240 and $480 \mathrm{mg}$ per day given for 14 days in healthy volunteers (46) which is in line with the results of Jiang et al (25).

\subsection{Cranberry}

Based on the results of Abdul et al (26) find that cranberry did not have a significant effect on warfarin (Table 1). Based on the pharmacodynamic parameters of warfarin after cranberry juice administration, there was a significant increase in the average value of AUC INR by $30 \%$ (Table 2) and it influences the platelet aggregation. It also supported by the results of Greenblatt et al (50) the activity of CYP2C9 did not affected by cranberry. Lilja et al (51) also examined the administration of cranberry juice for 5 days with warfarin, there was no significant change from AUC of S-warfarin.

However, the results of pharmacodynamic interactions of cranberry is different from $\mathrm{Li}$ et al (52) and Ansell et al (53), they found no significant changes in the warfarin response, but the volunteer by Li et al only 7 patients and Ansell (53) only 14 patients. Lilja et al (51) concluded the absence of pharmacodynamic interactions because of the dose of $10 \mathrm{mg}$ with cranberry juice administration for only 7 days. According to Hamann et al (54) based on case reports, there is a change in the INR after administration of cranberry juice, it can be detected with a longer period and use a high dose of warfarin like $56 \mathrm{mg}$ per week. From Abdul (26) we can conclude that the administration of cranberry for 2 weeks increased warfarin sensitivity to healthy volunteers, but did not have a pharmacokinetic effect, so the monitoring is needed regarding the use of warfarin with cranberry.

\subsection{St John's wort and Ginseng}

12 healthy volunteers were given $25 \mathrm{mg}$ of warfarin together with St. John's wort for 14 days and 7 days of ginseng (27). Co-administration of St. John's wort with warfarin at the recommended dose can increase the clearance of warfarin enantiomers and decrease the pharmacodynamic effects of warfarin. The administration of ginseng did not provide a significant difference to the pharmacokinetic parameters of warfarin (27).

There were significant differences of the AUC, $\mathrm{T}_{1 / 2}$, and $\mathrm{Cl} / \mathrm{F}$ of R-warfarin and S-warfarin by St. John's wort. While pharmacodynamic parameters show significant differences after the administration of warfarin with St. John's wort (Table 2). However, when warfarin was given with ginseng there is no significant differences, there was still a change in the value of INR and platelet aggregation (27).

St John's wort inhibits the activity of CYP2C9, CYP2D6, and CYP3A4 (55), but St John's wort also induction CYP1A2, CYP2E1, and CYP3A4 (56). The test of healthy volunteers for 14 days $S t$. John's wort induce CYP3A4 activity in the liver (56). This effect due to the existence of the pregnane $X$ receptor (PXR) (57). The influence of St. John's wort in the activity of the CYP450 enzyme is the cause of the pharmacokinetic changes from warfarin because these enzymes play a role in warfarin metabolism (27).

It can be concluded that St. John's wort has potential action with drugs whose metabolism is influenced by CYP2C9 and CYP3A4 substrates. The result of Jiang (27) can be evidence to support recommendations for monitoring the INR on patients when warfarin co-administration with drugs.

\subsection{Pomegranate Peel Extract and Guava Leaves Extract}

The results of Alnaqueeb et al (28) on administration of warfarin $0.5 \mathrm{mg} / \mathrm{kg}$ with 250 $\mathrm{mg} / \mathrm{kg}$ guava leaf extract and $100 \mathrm{mg} / \mathrm{kg}$ pomegranate peel extract for 5 days showed that it increased the value of protombine time (PT) and INR warfarin (Table 2). Elagitanins and elagic acid in pomegranate peel has a strong action in decreasing platelet aggregation in human plasma (58). It causes an increase in PT after pomegranate peel extract is given. While the effect of guava leaf extract on the PT and INR was also related to the antiplatelet activity of the flavonoids contained in it, especially quercetin which potentially increase the risk of bleeding (59).

The study pharmacokinetic interaction of warfarin showed that there was no significant 
effect of pomegranate peel extract on plasma warfarin concentration, this could be related to the low of elagitanin content in the extract. Although there was an increase in $\mathrm{C}_{\max }$ because the elagic acid and elagitanin could inhibit CYP3A and Pglycoprotein (60).

Pharmacokinetic interactions between warfarin and guava leaf extract significantly increase $C_{\max }$ (Table 1), and significantly change AUC and $\mathrm{Cl}$. It is caused by quercetin which can inhibit the activity of CYP2C9, CYP2C8 and CYP3A4 $(61,62)$. It can be concluded that the administration of warfarin simultaneously with pomegranate peel extract and guava leaf extract have pharmacokinetic and pharmacodynamic interaction.

\subsection{Curcumin}

Curcumin is an active ingredient of Curcuma longa that has been widely used as a food ingredient, has antioxidant activity, and anticancer activity $(63,64)$. Some studies report that curcumin has drug interactions. Liu et al.,(29) conducted warfarin $0.2 \mathrm{mg} / \mathrm{kg}$ with oral administration of 25 $\mathrm{mg} / \mathrm{kg}$ curcumin, $50 \mathrm{mg} / \mathrm{kg}$, and $100 \mathrm{mg} / \mathrm{kg}$ to rats for 7 days show that curcumin had no effect on pharmacodynamics of warfarin. However administration of $100 \mathrm{mg} / \mathrm{kg}$ of curcumin significantly increased $\mathrm{AUC}_{0-\infty}$ and $\mathrm{C}_{\max }$. When compared to the control group, $100 \mathrm{mg} / \mathrm{kg}$ of curcumin increased 1.6 times higher $\mathrm{AUC}_{0-\infty}$ value and 1.5 times higher of $\mathrm{C}_{\max }$, whereas plasma clearance decreased by $57.14 \%$ and there is no change in $T_{1 / 2}$. Interaction of warfarin and curcumin is achieved by inhibit P-glycoprotein and increase warfarin absorption.

In conclusion, the administration of curcumin at a dose of $100 \mathrm{mg} / \mathrm{kg}$ affects pharmacokinetics but does not affect the pharmacodynamics of warfarin (29). However, the co-administration of curcumin and warfarin must still be monitored to minimize the side effects.

\subsection{Caffeine}

Caffeine is widely consumed in the community so that it allows interactions with drugs. Coffee and tea are the main sources of caffeine. Zafar et al (30) showed that administration of $0.5 \mathrm{mg} / \mathrm{kg}$ warfarin and caffeine $5 \mathrm{mg} / \mathrm{kg}$ to rabbits has no significant effect on the $\mathrm{C}_{\max }, \mathrm{T}_{\max }$, and $\mathrm{Vd}$ (Table 1), but there were changes of warfarin $T_{1 / 2}$ when compared with the control group. This result indicates that multiple doses of caffeine increase $T_{1 / 2}$ of warfarin. Furthermore, the total clearance of warfarin when it was given together with caffeine was lower than control, caffeine reduced the elimination of warfarin from the body. Also, AUC has a significant increased (Table 1) after the administration of caffeine with warfarin, it means that caffeine inhibits warfarin metabolism. The inhibition is due to blocking CYP1A2 and CYP3A4 (30). In conclusion, caffeine can affect the pharmacokinetic profile of warfarin, so the coadministration of caffeine and warfarin needs to be reconsidered.

\subsection{Challenge and Future Perspective}

The co-administration of warfarin with herbs needs to be considered because they cause interactions. It is better to consume these herbs 1-2 hours after consuming warfarin to prevent their adverse effects. The effect of the pharmacokinetic interactions is an increase in drug levels in the blood, this can be dangerous, whereas the effects of this pharmacodynamic warfarin interaction are bleeding, bruising, fatigue, gastrointestinal effects, hemorrhage and thrombosis (65). In the future, more extensive research needs to be done to find out interactions with other herbs, in addition it is also necessary to do in depth research to study the mechanism of the interaction.

\section{Conclusion}

It can be concluded that some herbal medicines have significant interactions with warfarin based on pharmacokinetic and pharmacodynamic parameters. The herbs that affect the pharmacokinetics of warfarin are Danshen gegen, echinacea, St. John's wort and caffeine. While herbs those affect the pharmacodynamics of warfarin are policosanol, Ginkgo biloba, Cranberry, St. John's wort, ginseng, pomegranate peel, guava leaves and curcumin, so the administration of warfarin with those herbs need more concerned. 


\section{References}

1. Wardrop D, Keeling D. The story of the discovery of heparin and warfarin. 2008;(March):757-63.

2. Piatkov I, Rochester C, Jones T, Boyages S. Warfarin Toxicity and Individual VariabilityClinical Case. Toxins (Basel). 2010;2(11):2584-92.

3. Wadelius M, Chen LY, Downes K, Ghori J, Hunt S, Eriksson N, et al. Common VKORC1 and GGCX polymorphisms associated with warfarin dose. Pharmacogenomics J. 2005;5(4):262-70.

4. Varma M V, Pang SK, Isoherranen N, Zhao P. Dealing with the complex drug-drug interactions: Towards mechanistic models Manthena. Biopharm Drug Dispos. 2015;36:71-92.

5. Colet C, Amador TA, Heineck I. Drug Interactions and Adverse Events in a Cohort of Warfarin Users Attending Public Health Clinics. Int J Cardiovasc Sci. 2019;32(2):1107.

6. Ramsay NA, Kenny MW, Davies G, Patel JP. Complimentary and alternative medicine use among patients starting warfarin. $\mathrm{Br} J$ Haematol. 2005;130(5):777-80.

7. Ernst E, Pittler M, STevinson C, White A. The Desktop Guide to Complementary and Alternative Medicine. J Clin Pharmacol. 2002;54:71.

8. Qiu F, Wang G, Zhao Y, Sun H, Mao G, A J, et al. Effect of danshen extract on pharmacokinetics of theophylline in healthy volunteers. $\mathrm{Br} \mathrm{J}$ Clin Pharmacol. 2008;65(2):270-4.

9. Vieira MT, Huang S, Spring S. Botanical-Drug Interactions: A Scientific Perspective. 2012;1400-15.

10. Ngui JS, Chen Q, Shou M, Wang RW, Stearns RA, Baillie TA, et al. In vitro stimulation of warfarin metabolism by quinidine: Increases in the formation of 4'- and 10-hydroxywarfarin. Drug Metab Dispos. 2001;29(6):877-86.

11. Wadelius M, Chen LY, Eriksson N, Bumpstead S, Ghori J, Wadelius C, et al. Association of warfarin dose with genes involved in its action and metabolism. Hum Genet. 2007;121(1):23-34.

12. Zhang Z, Ge B, Zhou L, Lam TN, Zuo Z.
Induction of liver cytochrome P450s by Danshen-Gegen formula is the leading cause for its pharmacokinetic interactions with warfarin. $\mathrm{J}$ Ethnopharmacol [Internet]. 2014;154(3):672-86. Available from: http://dx.doi.org/10.1016/j.jep.2014.04.047

13. Unger M, Frank A. Simultaneous determination of the inhibitory potency of herbal extracts on the activity of six major cytochrome $\mathrm{P} 450$ enzymes using liquid chromatography/mass spectrometry and automated online extraction. Rapid Commun Mass Spectrom. 2004;18(19):2273-81.

14. Guo LQ, Yamazoe Y. Inhibition of cytochrome $\mathrm{P} 450$ by furanocoumarins in grapefruit juice and herbal medicines. Acta Pharmacol Sin. 2004;25(2):129-36.

15. Yale SH, Glurich I. Analysis of the Inhibitory Potential of Ginkgo biloba, Echinacea purpurea, and Serenoa repens on the Metabolic Activity of Cytochrome P450 3A4, 2D6, and 2C9. J alernative Complement Med. 2005;11(3):433-9.

16. Anderson GD, Rosito G, Mohustsy MA, Elmer GW. Drug interaction potential of soy extract and Panax ginseng. J Clin Pharmacol. 2003;43(6):643-8.

17. Guo LQ, Taniguchi M, Chen QY, Baba K, Yamazoe Y. Inhibitory potential of herbal medicines on human cytochrome P450mediated oxidation: Properties of Umbelliferous or Citrus crude drugs and their relative prescriptions. Jpn J Pharmacol. 2001;85(4):399-408.

18. Williamson E, Driver S, Baxter K. Herbal Medicines Interaction. USA: RPS Publishing; 2009. $432 \mathrm{p}$.

19. Bland TM, Haining RL, Tracy TS, Callery PS. CYP2C-catalyzed delta(9)tetrahydrocannabinol metabolism: Kinetics, pharmacogenetics and interaction with phenytoin. Biochem Pharmacol. 2005;70(7):1096-103.

20. Palleria C, Di Paolo A, Giofrè C, Caglioti C, Leuzzi G, Siniscalchi A, et al. Pharmacokinetic drug-drug interaction and their implication in clinical management. J Res Med Sci. 2013;18(7):600-9.

21. Tirona RG, Kim RB. Introduction to Clinical Pharmacology. Clin Transl Sci Princ Hum Res 
Second Ed. 2017;365-88.

22. Tripathi MM, Egawa S, Wirth AG, Tshikudi DM, Van Cott EM, Nadkarni SK. Clinical evaluation of whole blood prothrombin time (PT) and international normalized ratio (INR) using a Laser Speckle Rheology sensor. Sci Rep [Internet]. 2017;7(1):1-8. Available from: http://dx.doi.org/10.1038/s41598-017-08693-5

23. Zhou L, Wang S, Zhang Z, San Lau B, Pui Fung $\mathrm{K}$, Chung Leung $\mathrm{P}$, et al. Pharmacokinetic and pharmacodynamic interaction of Danshen-Gegen extract with warfarin and aspirin. $\mathrm{J}$ Ethnopharmacol [Internet]. 2012;143(2):648-55. Available from:

http://dx.doi.org/10.1016/j.jep.2012.07.029

24. Abdul MIM, Jiang X, Williams KM, Day RO, Roufogalis BD, Liauw WS, et al. Pharmacokinetic and pharmacodynamic interactions of echinacea and policosanol with warfarin in healthy subjects. $\mathrm{Br} \mathrm{J}$ Clin Pharmacol. 2010;69(5):508-15.

25. Jiang $X$, Williams KM, Liauw WS, Ammit AJ, Roufogalis BD, Duke CC, et al. Effect of ginkgo and ginger on the pharmacokinetics and pharmacodynamics of warfarin in healthy subjects. $\mathrm{Br} \mathrm{J}$ Clin Pharmacol. 2005;59(4):425-32.

26. Abdul MM, Jiang X, Williams KM, Day RO, Roufogalis BD, Liauw WS, et al. Pharmacodynamic interaction of warfarin with cranberry but not with garlic in healthy subjects. Br J Pharmacol. 2008;154(8):1691700 .

27. Jiang, X, Williams, K.M., Liauw WS. Effect of St John's wort and ginseng on the pharmacokinetics and pharmacodynamics of warfarin in healthy subjects. $\mathrm{Br} \mathrm{J}$ Clin Pharmacol. 2006;57(5):592-9.

28. Alnaqeeb M, Mansor KA, Idkaidek N, Qinna NA, Mallah EM, Ghanim BY. Critical pharmacokinetic and pharmacodynamic drugherb interactions in rats between warfarin and pomegranate peel or guava leaves extracts. BMC Complement Altern Med. 2019;19(1):112.

29. Liu AC, Zhao LX, Lou HX. Curcumin alters the pharmacokinetics of warfarin and clopidogrel in wistar rats but has no effect on anticoagulation or antiplatelet aggregation.
Planta Med. 2013;79(11):971-7.

30. Zafar S, Ali A, Ashraf MM, Khan JA, Aslam B, Naseer RD. Alteration in disposition kinetics of warfarin mediated by caffeine in healthy male albino rabbits. J Anim Plant Sci. 2019;29(1):158-65.

31. Chang Q, Sun L, Zhao RH, Chow MSS, Zuo Z. Simultaneous determination of ten active components in traditional Chinese medicinal products containing both gegen (Pueraria iobata) and danshen (Salvia miltiorrhiza) by high-performance liquid chromatography. Phytochem Anal. 2008;19(4):368-75.

32. Qin CZ, Ren X, Zhou HH, Mao XY, Liu ZQ. Inhibitory effect of salvianolate on human cytochrome P450 3A4 in vitro involving a noncompetitive manner. Int J Clin Exp Med. 2015;8(9):15549-55.

33. Wang BQ. Salvia miltiorrhiza chemical and pharmacological review of a medicinal plant. J Med Plants Res. 2010;4(25):2813-20.

34. Lin Y-L, Don M-J, Kuo Y-H, Chen R-M, Ueng Y-F. Induction of cytochrome P450dependent monooxygenase by extracts of the medicinal herb Salvia miltiorrhiza . J Pharm Pharmacol. 2006;58(4):521-7.

35. Ueng YF, Kuo YH, Peng HC, Chen TL, Jan WC, Guengerich FP, et al. Diterpene quinone tanshinone IIA selectively inhibits mouse and human cytochrome P4501A2. Xenobiotica. 2003;33(6):603-13.

36. Barnes J, Anderson LA, Gibbons S, Phillipson JD. Echinacea species ( Echinacea angustifolia (DC.) Hell., Echinacea pallida (Nutt.) Nutt., Echinacea purpurea (L.) Moench): a review of their chemistry, pharmacology and clinical properties . J Pharm Pharmacol. 2005;57(8):929-54.

37. Irmak S, Dunford NT, Milligan J. Policosanol contents of beeswax, sugar cane and wheat extracts. Food Chem. 2006;95(2):312-8.

38. Gouni-Berthold I, Berthold HK. Policosanol: Clinical pharmacology and therapeutic significance of a new lipid-lowering agent. Am Heart J. 2002;143(2):356-65.

39. Gorski JC, Huang SM, Pinto A, Hamman MA, Hilligoss JK, Zaheer NA, et al. The effect of echinacea (Echinacea purpurea root) on cytochrome $\mathrm{P} 450$ activity in vivo. Clin Pharmacol Ther. 2004;75(1):89-100. 
40. Castano G, Mas R, Fernandes L, Illnait J, Games R, Alvarez E. Effects of policosanol 20 versus $40 \mathrm{mg} /$ day in the treatment of patients with type II hypercholesterolemia : a 6-month. Int J Clin Pharmacol Res. 2001;21(1):43-57.

41. Reiner $\check{Z}$, Tedeschi-Reiner E. Rice policosanol does not have any effects on blood coagulation factors in hypercholesterolemic patients. Coll Antropol. 2007;31(4):1061-4.

42. Hummel MA, Locuson CW, Gannett PM, Rock DA, Mosher CM, Rettie AE, et al. CYP2C9 genotype-dependent effects on in vitro drug-drug interactions: Switching of benzbromarone effect from inhibition to activation in the CYP2C9.3 variant. Mol Pharmacol. 2005;68(3):644-51.

43. Kumar V, Wahlstrom JL, Rock DA, Warren CJ, Gorman LA, Tracy TS. CYP2C9 inhibition: Impact of probe selection and pharmacogenetics on in vitro inhibition profiles. Drug Metab Dispos. 2006;34(12):1966-75.

44. Engelsen J, Nielsen JD, Winther K. Effect of coenzyme Q10 and Ginkgo biloba on warfarin dosage in stable, long-term warfarin treated outpatients . A randomised, double blind, placebo-crossover trial variation in relative risk of venous thromboembolism in different cancers. Thromb Haemost. 2002;87(6):10756.

45. Ohnishi N, Kusuhara M, Yoshioka M, Kuroda K, Soga A, Nishikawa F, et al. Studies on interactions between functional foods or dietary supplements and medicines. I. Effects of Ginkgo biloba leaf extract on the pharmacokinetics of diltiazem in rats. Biol Pharm Bull. 2003;26(9):1315-20.

46. Sollier BD, Caplain H, Drouet L. No alteration in platelet function or coagulation induced by EGb761 in a controlled study. Clin Lab Haematol. 2003;25(4):251-3.

47. Zou L, Harkey MR, Henderson GL. Effects of herbal components on cDNA-expressed cytochrome P450 enzyme catalytic activity. Life Sci [Internet]. 2002;71(13):1579-89. Available

from: http://www.ncbi.nlm.nih.gov/entrez/query.fcgi ?cmd=Retrieve $\& \mathrm{db}=$ PubMed $\& d o p t=$ Citation \&list_uids $=12127912$

48. Nash KM, Shah ZA. Current perspectives on the beneficial role of Ginkgo biloba in neurological and cerebrovascular disorders. Integr Med Insights. 2015;10:1-9.

49. Umegaki $\mathrm{K}$, Shinozuka $\mathrm{K}$, Watarai $\mathrm{K}$, Takenaka H, Yoshimura M, Daohua P, et al. Ginkgo biloba extract attenuates the development of hypertension in deoxycorticosterone acetate-salt hypertensive rats. Clin Exp Pharmacol Physiol. 2000;27(4):277-82.

50. Greenblatt DJ, Von Moltke LL, Perloff ES, Luo Y, Harmatz JS, Zinny MA. Interaction of flurbiprofen with cranberry juice, grape juice, tea, and fluconazole: In vitro and clinical studies. Clin Pharmacol Ther. 2006;79(1):12533.

51. Lilja JJ, Backman JT, Neuvonen PJ. Effects of daily ingestion of cranberry juice on the pharmacokinetics of warfarin, tizanidine, and midazolam - Probes of CYP2C9, CYP1A2, and CYP3A4. Clin Pharmacol Ther. 2007;81(6):833-9.

52. Li Z, Seeram NP, Carpenter CL, Thames G, Minutti C, Bowerman S. Cranberry Does Not Affect Prothrombin Time in Male Subjects on Warfarin. J Am Diet Assoc. 2006;106(12):2057-61.

53. Ansell J, McDonough M, Harmatz JS, Greenblatt DJ. A randomized, double-blind trial of the interaction between cranberry juice and warfarin. $\mathrm{J}$ Thromb Thrombolysis. 2008;25(1):112-112.

54. Hamann GL, Campbell JD, George CM. Warfarin-cranberry juice interaction. Ann Pharmacother. 2011;45(3).

55. Budzinski JW, Foster BC, Vandenhoek S, Arnason JT. An in vitro evaluation of human cytochrome P450 3A4 inhibition by selected commercial herbal extracts and tinctures. Phytomedicine. 2000;7(4):273-82.

56. Wang Z, Christopher J. The Effect of St John's Wort (Hypericum perforatum) on Human Cytochrome P450 Activity. Clin Pharmacol Ther. 2001;

57. Robertson GR, Field J, Goodwin B, Bierach S, Tran M, Lehnert A, et al. Transgenic mouse models of human CYP3A4 gene regulation. Mol Pharmacol. 2003;64(1):42-50.

58. Mattiello T, Trifirò E, Jotti GS, Pulcinelli FM. Effects of pomegranate juice and extract 
polyphenols on platelet function. J Med Food. 2009;12(2):334-9.

59. Mozzicafreddo M, Cuccioloni M, Eleuteri AM, Fioretti E, Angeletti M. Flavonoids inhibit the amidolytic activity of human thrombin. Biochimie. 2006;88(9):1297-306.

60. Athukuri BL, Neerati P. Enhanced Oral Bioavailability of Diltiazem by the Influence of Gallic Acid and Ellagic Acid in Male Wistar Rats: Involvement of CYP3A and P-gp Inhibition. Phyther Res. 2017;31(9):1441-8.

61. Kaneko K, Suzuki K, Iwadate-Iwata E, Kato I, Uchida K, Onoue M. Evaluation of food-drug interaction of guava leaf tea. Phyther Res. 2013;27(2):299-305.

62. Si D, Wang Y, Zhou YH, Guo Y, Wang J,
Zhou H, et al. Mechanism of CYP2C9 inhibition by flavones and flavonols. Drug Metab Dispos. 2009;37(3):629-34.

63. Kim DC, Lee W, Bae JS. Vascular antiinflammatory effects of curcumin on HMGB1mediated responses in vitro. Inflamm Res. 2011;60(12):1161-8.

64. Li Y, Revalde JL, Reid G, Paxton JW. Modulatory effects of curcumin on multi-drug resistance-associated protein 5 in pancreatic cancer cells. Cancer Chemother Pharmacol. 2011;68(3):603-10.

65. Shuaib W, Iftikhar H, Alweis R, Shahid H. Warfarin Therapy: Survey of Patients Knowledge of their Drug Regimen. 2014;21(4):37-41. 